\section{Home environment} opportunities and motor development of infants in the first year

\author{
Oportunidades do ambiente
}

domiciliar e desenvolvimento

motor de lactentes no

primeiro ano

Érica Cesário Defilipo (1) ${ }^{1 *}$

Elton Duarte Dantas Magalhães (1) ${ }^{1}$

Caroline Miranda Máltaro (10 ${ }^{2}$

Larissa Carvalhaes de Oliveira (1) ${ }^{3}$

Ana Luiza Oliveira Neimerck (1) ${ }^{1}$

Alessa Sin Singer Brugiolo (ib ${ }^{1}$

\footnotetext{
${ }^{1}$ Universidade Federal de Juiz de Fora (UFJF), Governador Valadares, MG, Brazil

${ }^{2}$ Hospital Metropolitano Odilon Behrens, Belo Horizonte MG, Brazil

${ }^{3}$ Hospital Infantil João Paulo II, Belo Horizonte, MG, Brazil
}

Date of first submission: December 20, 2020

Last received: February 19, 2021

Accepted: March 2, 2021

Associate editor: Ana Paula Cunha Loureiro

\footnotetext{
*Correspondence: ericadefilipo@yahoo.com.br
}

\begin{abstract}
Introduction: The home environment is a fundamental agent for infant development in the first year of life. Objective: To evaluate the opportunities for environmental stimulation and the motor development of infants at 3, 6, 9, and 12 months of age and determine the association between these opportunities and the parents' schooling and economic levels, at each age studied.

Methods: This is a longitudinal study using the Alberta Infant Motor Scale (AIMS) to assess motor development, the Affordances in the Home Environment for Motor Development - Infant Scale (AHEMD-IS) questionnaire to assess the stimulation opportunities at home, and the Brazilian Association of Research Companies (ABEP) questionnaire to classify the economic level of the families. The association between opportunities for environmental stimulation and schooling and economic levels was determined by the chi-squared test. Results: Thirtyseven infants participated, $54.1 \%$ of whom were boys. At 3 months of age, the opportunities for environmental stimulation were unsatisfactory, while at 6, 9, and 12 months satisfactory opportunities predominated. Three infants scored below $10 \%$ on the AIMS at 3 months of age, indicating delayed motor development. There was a significant association between economic level and total AHEMD-IS score $(p=0.031)$, and the toy dimension for gross $(p=0.016)$ and fine $(p=0.043)$ motor skills.

Conclusion: The infants' home environment did not provide sufficient opportunities for stimulation in the first months, but improved during the first year. Motor development was considered delayed for three infants, but was suitable in subsequent evaluations.
\end{abstract}

Keywords: Child development. Child health. Growth and development. Residence characteristics. 


\section{Resumo}

Introdução: $O$ ambiente domiciliar é um agente fundamental para o desenvolvimento do lactente no primeiro ano de vida. Objetivo: Avaliar as oportunidades do ambiente domiciliar e o desenvolvimento motor de lactentes aos 3, 6, 9 e 12 meses de idade e verificar se há associação entre as oportunidades de estimulação e a escolaridade e nível econômico dos pais, em cada faixa etária estudada. Métodos: Estudo longitudinal, que utilizou o instrumento Alberta Infant Motor Scale para avaliar o desenvolvimento motor, o questionário Affordances in the Home Environment for Motor Development - Infant Scale (AHEMDIS) para avaliar as oportunidades de estimulação oferecidas no domicílio e o questionário da Associação Brasileira de Empresas de Pesquisa para classificar o nível econômico das famílias. A associação entre as oportunidades de estimulação do ambiente e a escolaridade e nível econômico foi verificada pelo teste qui-quadrado. Resultados: Participaram da pesquisa 37 lactentes, sendo 54,1\% do sexo masculino. Aos 3 meses de idade, as oportunidades de estimulação do ambiente foram insatisfatórias. Aos 6, 9 e 12 meses, houve predomínio de oportunidades satisfatórias. Três lactentes apresentaram percentil inferior a $10 \%$ aos 3 meses de idade, indicando atraso do desenvolvimento motor. Houve associação significativa entre o nível econômico e a pontuação total do AHEMD-IS $(p=0,031)$, a dimensão brinquedos de motricidade grossa $(p=0,016)$ e fina $(p=0,043)$. Conclusão: $O$ ambiente domiciliar dos lactentes estudados apresentou oportunidades insuficientes para estimulação nos primeiros meses, melhorando ao longo do primeiro ano. O desenvolvimento motor foi considerado atrasado para três lactentes, tornando-se adequado nas avaliações subsequentes.

Palavras-chave: Desenvolvimento infantil. Saúde da criança. Crescimento e desenvolvimento. Características de residência.

\section{Introduction}

Motor development is characterized by changes in motor skills over time, caused by the interaction between biological, genetic and environmental processes. ${ }^{1}$ Significant improvements in motor skills occur during childhood, evolving to more complex abilities. ${ }^{2}$

The first year of life is extremely important for child development, since motor skills progress rapidly, allowing greater mobility. ${ }^{3}$
Monitoring motor development is important because impaired development can have negative consequences over the course of an individual's life. ${ }^{4}$ Thus, assessing child development in the first year should include not only biological aspects, but also analysis and monitoring of environmental factors. ${ }^{2}$ Economic conditions, parental schooling, family dynamic, family purchasing power, family relations, characteristics of the physical environment, availability of toys and the variability of stimulation provided by the parents are critical indicators of environmental quality that may influence child development. ${ }^{2,5,6}$ Studies demonstrate that children living in environments with little stimulation, ${ }^{2}$ from families with low purchasing power and low schooling levels, more frequently exhibit delayed motor development. ${ }^{7}$

Given that infants tend to spend most of their time at home during the first year of life, this environment becomes a crucial factor for motor development. ${ }^{8}$ Thus, the present study aimed at assessing home environment opportunities and the development of infants at 3,6, 9 and 12 months of age and determine whether there is an association between environmental stimulation opportunities and parental schooling and economic level, at each age studied.

\section{Methods}

This is a longitudinal observational study of infants born at the Municipal Hospital of Governador Valadares, participants of the research project entitled "Factors associated with prematurity and low birthweight in Governador Valadares, Minas Gerais: a case-control study". ${ }^{9}$ Excluded were infants exhibiting the following at birth: congenital malformation, diagnosis of congenital infection, neurological impairment, genetic syndrome, imaging diagnosis of grade III or IV intracranial and/ or periventricular leukomalacia hemorrhage and/or intracranial cysts or abscesses, diagnosis of severe bronchopulmonary dysplasia, hearing or vision problems, cardiorespiratory or orthopedic alterations.

The parents/guardians of pre-selected infants were contacted by telephone to explain the objectives and procedures of the study, and schedule assessments for those who agreed to participate. Previously trained researchers conducted the assessments at the Clinical Physiotherapy School of the Federal University of Juiz 
de Fora - Governador Valadares Campus (UFJF-GV). The infants were assessed at 3, 6, 9 and 12 months of age, the corrected age being considered for premature babies.

Initial data collection included information on sex, date of birth, gestational age and birthweight. Next, the Brazilian Association of Research Companies (ABEP) questionnaire was used to assess the family's economic level, classifying the population into the following economic strata: A, B1, B2, C1, C2 and D/E, A being the highest economic level and $D / E$, the lowest. ${ }^{10}$

The Affordances in the Home Environment for Motor Development-Infant Scale (AHEMD-IS) instrument, filled out by the parents, was used to evaluate opportunities at home, divided into four dimensions: physical space, variety of stimulations, and gross and fine motor skills toys. ${ }^{8}$ The scores were converted into four descriptive categories: "less than adequate", "moderately adequate", "adequate" and "excellent", which provides information on the opportunities at home for infant motor development. ${ }^{8}$ Parental schooling and a number of home characteristics were also obtained from this questionnaire.

The Alberta Infant Motor Scale (AIMS) was used to assess motor development by observing spontaneous movement and motor skills in the prone, supine, sitting and standing positions, considering motor development delay at less than $10 \% .{ }^{11,12}$ The assessors were trained to apply the scale and the intra and interrater reliability was above 0.80 .

The data collected were analyzed using the Statistical Package for the Social Sciences (SPSS) 14.0. Descriptive analysis of the variables was carried out to characterize the study population. In order to determine the association between economic level, parental schooling and the stimulation opportunities of the environment, participants were grouped due to the small sample size. According to the economic level, participants were grouped into the highest (B1, B2, C1) and lowest classes $(\mathrm{C} 2, \mathrm{D} / \mathrm{E})$. Parental schooling was divided into high (secondary and university education) and low (incomplete secondary or lower). Stimulation opportunities at home, considering the total AHEMD-IS score and dimension, were classified as "less than adequate or moderately adequate" and "adequate or excellent". The association between the variables studied was determined using the chi-squared test, with a p-value $<0.05$ considered statistically significant.

The study was approved by the Human Research Ethics Committee of the Federal University of Juiz de Fora (CAAE63962617.9.0000.5147) on March 20, 2017. All the parents or guardians that agreed to take part were informed of the study objectives and procedures and provided written informed consent.

\section{Results}

A total of 183 parents/guardians of the infants were contacted, 37 of whom were assessed at 3 months, 21 at 6 months, 18 at 9 months, and 10 at 12 months.
There was a predominance of boys in the sample (54.1\%). With respect to gestational age and birthweight, $32.4 \%$ were preterm and $21.6 \%$ had low birthweight. In regard to family economic level, $51.4 \%$ of participants exhibited a high economic level (B1/B2/C1). Most mothers and fathers had high schooling $(62.2 \%$ and $81.1 \%$, respectively). Home characteristics showed a predominance of families living in houses (86.5\%) with an outdoor yard (83.8\%). A majority of homes (62.2\%) contained two adults and two children (40.5\%), followed by only one child (37.8\%). The descriptive characteristics of the participants are presented in Table 1.

Table 1 - Descriptive characteristics of the participants $(n=37)$

\begin{tabular}{|c|c|c|}
\hline Variables & $f$ & $\%$ \\
\hline \multicolumn{3}{|l|}{ Sex } \\
\hline Female & 17 & 45.9 \\
\hline Male & 20 & 54.1 \\
\hline \multicolumn{3}{|l|}{ Gestational age } \\
\hline Term & 25 & 67.6 \\
\hline Preterm & 12 & 32.4 \\
\hline \multicolumn{3}{|l|}{ Birthweight } \\
\hline Adequate weight & 29 & 78.4 \\
\hline Low birthweight & 8 & 21.6 \\
\hline \multicolumn{3}{|l|}{ ABEP } \\
\hline High economic level (B1, B2, C1) & 19 & 51.4 \\
\hline Low economic level (C2, D/E) & 18 & 48.6 \\
\hline \multicolumn{3}{|l|}{ Father's schooling } \\
\hline Low (incomplete secondary or lower) & 14 & 37.8 \\
\hline High (secondary or university) & 23 & 62.2 \\
\hline \multicolumn{3}{|l|}{ Mother's schooling } \\
\hline Low (incomplete secondary or lower) & 7 & 18.9 \\
\hline High (secondary or university) & 30 & 81.1 \\
\hline \multicolumn{3}{|l|}{ Type of residence } \\
\hline Apartment & 5 & 13.5 \\
\hline House & 32 & 86.5 \\
\hline \multicolumn{3}{|l|}{ Outdoor yard } \\
\hline Yes & 31 & 83.8 \\
\hline No & 6 & 16.2 \\
\hline \multicolumn{3}{|l|}{ Number of children in the home } \\
\hline 1 & 14 & 37.8 \\
\hline 2 & 15 & 40.5 \\
\hline 3 or more & 8 & 21.7 \\
\hline \multicolumn{3}{|l|}{ Number of adults in the home } \\
\hline 1 & 4 & 10.8 \\
\hline 2 & 23 & 62.2 \\
\hline 3 or more & 10 & 27.0 \\
\hline
\end{tabular}

Note: $\mathrm{ABEP}=$ Economic Classification Criteria of the Brazilian Association of Research Companies; $n=$ sample number; $f=$ frequency.

At 3 months of age, stimulation opportunities at home, assessed by the total score on the AHEMD-IS, were unsatisfactory for most of the participating families and classified as "less than adequate" and "moderately adequate" (70.2\%). At 6 months of age, this classification changed to "adequate" or "excellent" for $66.7 \%$ of 
the participants. At 9 and 12 months, there was also a predominance of satisfactory opportunities (classified as "adequate" or "excellent") for more than $60 \%$ of the subjects.

Separate analysis of each dimension of the AHEMD-IS instrument showed that opportunities were unsatisfactory for the physical space dimension at $3(62.1 \%)$ and 6 months $(57.1 \%)$. In the variety of stimulation dimension, opportunities were unsatisfactory at $9(61.1 \%)$ and 12 months (60.0\%). Opportunities in the gross motor toys dimension were unsatisfactory at 3 (70.3\%) and 9 months (55.6\%). Finally, in the fine motor toys dimension, stimulation opportunities at home were considered unsatisfactory at 3 (81.1\%), 6 (57.1\%) and 12 months of age (50.0\%). Total AHEMD-IS score and the dimensions for each age are shown in Table 2.

The results obtained in AIMS assessment show that at 3 months of age, three infants were below 10\%, indicating delayed motor development. It is important to underscore that these three infants were term-born with adequate birthweight and that the families had high schooling levels and a good economic situation. However, two of the infants had unsatisfactory stimulation opportunities at home at that age. In subsequent assessments, all the infants displayed adequate motor development at all the ages studied (Table 3).

Table 2 - Classification of total AHEMD-IS score and dimensions

\begin{tabular}{|c|c|c|c|c|}
\hline AHEMD-IS & $\begin{array}{c}3 \text { months } \\
(n=37)\end{array}$ & $\begin{array}{c}6 \text { months } \\
(n=21)\end{array}$ & $\begin{array}{c}9 \text { months } \\
(n=18)\end{array}$ & $\begin{array}{c}12 \text { months } \\
(n=10)\end{array}$ \\
\hline Total score & $f(\%)$ & $f(\%)$ & $f(\%)$ & $f(\%)$ \\
\hline Less than adequate & $13(35.1)$ & $2(9.5)$ & $1(5.6)$ & $2(20.0)$ \\
\hline Moderately adequate & $13(35.1)$ & $5(23.8)$ & $6(33.3)$ & $2(20.0)$ \\
\hline Adequate & $6(16.2)$ & $5(23.8)$ & $8(44.4)$ & $2(20.0)$ \\
\hline Excellent & $5(13.5)$ & $9(42.9)$ & $3(16.7)$ & $4(40.0)$ \\
\hline \multicolumn{5}{|l|}{ Physical Space } \\
\hline Less than adequate & $5(13.5)$ & $8(38.1)$ & $0(0.0)$ & $1(10.0)$ \\
\hline Moderately adequate & $18(48.6)$ & $4(19.0)$ & $8(44.4)$ & $4(40.0)$ \\
\hline Adequate & $13(35.1)$ & $6(28.6)$ & $7(38.9)$ & $1(10.0)$ \\
\hline Excellent & $1(2.7)$ & $3(14.3)$ & $3(16.7)$ & $4(40.0)$ \\
\hline \multicolumn{5}{|l|}{ Variety of Stimulation } \\
\hline Less than adequate & $4(10.8)$ & $2(9.5)$ & $5(27.8)$ & $3(30.0)$ \\
\hline Moderately adequate & $9(24.3)$ & $2(9.5)$ & $6(33.3)$ & $3(30.0)$ \\
\hline Adequate & $15(40.5)$ & $6(28.6)$ & $3(16.7)$ & $1(10.0)$ \\
\hline Excellent & $9(24.3)$ & $11(52.4)$ & $4(22.2)$ & $3(30.0)$ \\
\hline \multicolumn{5}{|l|}{ Gross motor toys } \\
\hline Less than adequate & $19(51.4)$ & $6(28.6)$ & $3(16.7)$ & $2(20.0)$ \\
\hline Moderately adequate & $7(18.9)$ & $4(19.0)$ & $7(38.9)$ & $1(10.0)$ \\
\hline Adequate & $9(24.3)$ & $8(38.1)$ & $5(27.8)$ & $2(20.0)$ \\
\hline Excellent & $2(5.4)$ & $3(14.3)$ & $3(16.7)$ & $5(50.0)$ \\
\hline \multicolumn{5}{|l|}{ Fine motor toys } \\
\hline Less than adequate & $28(75.7)$ & $8(38.1)$ & $2(11.1)$ & $3(30.0)$ \\
\hline Moderately adequate & $2(5.4)$ & $4(19.0)$ & $6(33.3)$ & $2(20.0)$ \\
\hline Adequate & $4(10.8)$ & $3(14.3)$ & 7 (38.9) & $4(40.0)$ \\
\hline Excellent & $3(8.1)$ & $6(28.6)$ & $3(16.7)$ & $1(10.0)$ \\
\hline
\end{tabular}

Note: AHEMD-IS = Affordances in the Home Environment for Motor Development - Infant Scale; $\mathrm{n}=$ sample number for each age; $f=$ frequency. 
The association between stimulation opportunities at home (total AHEMD-IS score and dimensions), parental schooling and family economic level (ABEP) was also analyzed at each age studied. At 3 months of age there was a statistically significant association between economic level and the fine motor toys dimension $(p=0.043)$. At 6 months, there was a statistically significant association between economic level and the gross motor toys dimension $(p=0.016)$ and between economic level and total AHEMD-IS score $(p=0.031)$ (Table 4). At 9 and
12 months, no statistically significant associations were found between stimulation opportunities at home and schooling and economic levels. All the variables were analyzed, but due to their large number, only those with significant associations $(p<0.05)$ are presented in Table 4. We were unable to determine the association between opportunities at home and motor development owing to the small number of participants and because only three infants displayed delayed development, in a single assessment.

Table 3 - Classification of motor development and percentages according to the AIMS

\begin{tabular}{|c|c|c|c|c|}
\hline AIMS percentage & $\begin{array}{c}3 \text { months } \\
f(\%)\end{array}$ & $\begin{array}{c}6 \text { months } \\
f(\%)\end{array}$ & $\begin{array}{c}9 \text { months } \\
f(\%)\end{array}$ & 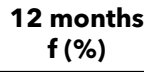 \\
\hline$<5 \%$ & $1(2.7)$ & - & - & - \\
\hline $5 \%$ & $1(2.7)$ & - & - & - \\
\hline Between 5 and $10 \%$ & $1(2.7)$ & - & - & - \\
\hline $10 \%$ & $1(2.7)$ & $1(4.8)$ & - & - \\
\hline Between 10 and $25 \%$ & $821.6)$ & $2(9.5)$ & - & - \\
\hline $25 \%$ & $3(8.1)$ & - & $3(16.7)$ & - \\
\hline Between 25 and $50 \%$ & $4(10.8)$ & $3(14.3)$ & $3(16.7)$ & $1(10.0)$ \\
\hline $50 \%$ & 5 13.5) & - & - & - \\
\hline Between 50 and $75 \%$ & $3(8.1)$ & $6(28.6)$ & $4(22.2)$ & - \\
\hline $75 \%$ & $3(8.1)$ & - & $1(5.6)$ & $3(30.0)$ \\
\hline Between 75 and $90 \%$ & $1(2.7)$ & $2(9.5)$ & $5(27.8)$ & - \\
\hline $90 \%$ & $4(10.8)$ & $1(4.8)$ & $2(11.1)$ & $6(60.0)$ \\
\hline$>90 \%$ & $2(5.4)$ & $6(28.6)$ & - & - \\
\hline \multicolumn{5}{|l|}{ Motor development } \\
\hline Adequate & 34 (91.9) & $21(100)$ & $18(100)$ & $10(100)$ \\
\hline Delayed & $3(8.1)$ & - & - & - \\
\hline
\end{tabular}

Note: AIMS= Alberta Infant Motor Scale; $f=$ frequency.

Table 4 - Association between AHEMD-IS and ABEP

\begin{tabular}{|c|c|c|c|c|}
\hline \multirow{2}{*}{ Age } & \multirow{2}{*}{ AHEMD-IS } & \multicolumn{2}{|c|}{ ABEP } & \multirow[b]{2}{*}{$\mathbf{p}$} \\
\hline & & $\begin{array}{c}\text { Highest level } \\
f(\%)\end{array}$ & $\begin{array}{c}\text { Lowest level } \\
\mathbf{f}(\%)\end{array}$ & \\
\hline \multirow[t]{3}{*}{3 months } & Fine motor toys & & & \\
\hline & Less than or moderately adequate & $13(68.4)$ & $17(94.4)$ & $0.043^{*}$ \\
\hline & Adequate or excellent & $6(31.6)$ & $1(5.6)$ & \\
\hline \multirow[t]{6}{*}{6 months } & Gross motor toys & & & \\
\hline & Less than or moderately adequate & $2(20.0)$ & $8(72.7)$ & $0.016^{*}$ \\
\hline & Adequate or excellent & $8(80.0)$ & $3(27.3)$ & \\
\hline & Total score & & & \\
\hline & Less than or moderately adequate & $1(10.0)$ & $6(54.5)$ & $0.031^{\star}$ \\
\hline & Adequate or excellent & $9(10.0)$ & $5(45.4)$ & \\
\hline
\end{tabular}

Note: AHEMD-IS = Affordances in the Home Environment for Motor Development - Infant Scale; ABEP = Economic Classification Criteria of the Brazilian Association of Research Companies; $f=$ frequency. * $p$-valor $<0,05$. 


\section{Discussion}

Child development is a continuous process of change that occurs during childhood and whose course throughout life may be influenced by several aspects. These include biological factors, such as prematurity and low birthweight, which lead to biological immaturity and put the child's nutritional status at risk. ${ }^{13-15}$ Although these biological factors may affect development, none of the premature or low birthweight infants exhibited delayed motor development during the first year of life.

Environmental factors may also influence child development. ${ }^{13}$ The home, which is the first environment experienced by the child, can strengthen or compromise development depending on its characteristics, exposure and availability of stimulation, and may also contribute to attenuating or overcoming the effects of biological risk factors. ${ }^{13}$

Given that the home is an important agent for learning and development, researchers have investigated the relation between the environment and aspects of motor development. ${ }^{16-18}$ Studies demonstrate that the risk factors that can influence motor development include home characteristics, physical space, family income, availability of toys and parental behavior. ${ }^{19-22}$ In the present study, the stimulation opportunities at the child's home were considered unsatisfactory in the third month, highlighting the gross and fine motor toy dimension, which exhibited greater predominance of low classifications. This result corroborates the crosssectional study of Defilipo et al., ${ }^{5}$ who assessed 229 infants aged 3 to 18 months and their families, residents of the municipality of Juiz de Fora, Minas Gerais state, and found that environmental stimulation was relatively low for the study population. This result also resembles that reported by Nobre et al. ${ }^{23}$ in the municipality of Juazeiro do Norte, Ceará state, who reported that the opportunities at the participants' homes were insufficient for motor development, showing a predominance of inadequate residential structures and the nonexistence of sufficient materials for the development of the children's gross and fine motor skills.

With respect to the age of 3 months, which showed unsatisfactory stimulation opportunities, the AIMS result revealed that three infants of that age obtained a result of less than $10 \%$, indicating delayed motor development. It is important to underscore that two of these three infants had insufficient opportunities at home. Given that stimulation opportunities at home are positively associated with the motor development of children, ${ }^{24}$ and that the home provides resources that can significantly influence motor skills development, the fact that these infants did not receive adequate stimulation ${ }^{25}$ could explain the delayed development observed.

In the first assessment at 3 months of age, the questionnaire completed by the parents revealed that many of the infants had no toys at home, that the parents reported not knowing the importance of toys at this age and because they believed that their child would not be able to explore toys independently, had not provided any. Studies suggest that home environments that favor access to stimulating devices, that is, toys, can provide more adequate stimulation for motor development. The use of appropriate toys may stimulate new and varied motor actions, help eye-hand coordination and favor the development of manual skills. ${ }^{19}$

At the assessments at 6,9 and 12 months, the results for motor development stimulation opportunities were more positive, given that all the infants exhibited adequate motor development for their age according to the AIMS, with a predominance of "adequate" and "excellent" classification for most of the participants. It is believed that the improvement in environmental opportunities may be because the AHEMD-IS questionnaire is self-explicative, containing questions on daily stimulation and images of more adequate toys, which may have contributed to guiding the parents. As reported by Miquelote et al., ${ }^{21}$ who assessed 32 infants from São Paulo state, after the first application of the AHEMD-IS, the parents were able to visually identify the ideal toys and understand that they needed to acquire them, thereby improving environmental stimulation and enhancing the child's motor development. It is believed that this is what occurred in the present study, which may have contributed to increasing the stimulation opportunities observed in subsequent assessments.

Economic level showed a statistically significant association with the total AHEMD-IS score at 6 months, indicating that families with greater purchasing power provided better environmental stimulation opportunities, corroborating the results of other studies. ${ }^{5,26}$ According to the literature, families with higher income can acquire homes with better physical structures, purchase better toys, have greater access to knowledge about the factors that may influence motor development, and are capable of providing better stimulation for their children. ${ }^{5,23}$ 
Valadi and Gabbard ${ }^{25}$ observed that family income alone can affect the quality and quantity of the resources available at home, indicating that families with higher incomes provide more resources than their middle and low-income counterparts. Similarly, studies reveal that low economic levels seem to increase infant vulnerability, which, along with risky environments, may compromise motor development. ${ }^{5,23,26}$ Added to this scenario is the marked economic inequality in the Brazilian population, ${ }^{17}$ which may be an aggravating factor for the risk of delayed childhood motor development. ${ }^{27}$

Economic level also exhibited a statistically significant association with fine and gross motor toys at 3 and 6 months, respectively, indicating that families with greater purchasing power provided more toys at home. Studies that used the AHEMD-IS instrument demonstrated the influence of socioeconomic level on the availability of toys. ${ }^{21,28}$ Children from families with higher incomes perform better in fine and gross motor skills compared to their low-income counterparts, ${ }^{25}$ which may be due to the greater availability of toys. The high price of children's toys in Brazil may preclude some low-income families from acquiring them.

In the present study, no significant association was found between opportunities at home and parental education. However, studies suggest that for many families, income and education are the main environmental restrictions that can impact the stimulation present in a domestic environment, including the availability of toys. ${ }^{5,25,29}$ According to Zoghi et al., ${ }^{29}$ better parental schooling, especially the mother's, may play an important role in child development.

A limitation of this study was the small number of participants despite the large sample size during assessments, a fact commonly found in longitudinal studies. A total of 183 families were invited to take part. It is believed that the parents' lack of information regarding the importance of development in the first year of life, as well as the need to conduct research in the area of child development, may have interfered in recruitment. Added to this is the fact that some of the recruited families do not live in the city where the study was carried out, which may have hindered their access to the assessments. In addition, since most of the participating infants displayed adequate development, the parents or guardians may not have been concerned about the need for continual monitoring, which led to their abandoning the study.

\section{Conclusion}

The home environment of the infants assessed provided insufficient stimulation opportunities in the initial months, but improved throughout the first year of life. At 3 months of age, three infants exhibited delayed motor development, which became adequate at subsequent assessments. Families with higher economic levels provided better stimulation opportunities and acquired more toys for their children. The results of this study may contribute to developing programs and policies in the area of childhood health aimed at improving the stimulation opportunities for infants at home, and primarily demonstrating to parents the importance of providing appropriate toys.

\section{Authors' contributions}

All the authors participated in the study design and planning, data collection, analysis and interpretation of the data, writing of the manuscript and approved the version to be published.

\section{References}

1. Ribeiro CC, Pachelli MRO, Amaral NCO, Lamônica DAC. Development skills of children born premature with low and very low birth weight. CoDAS. 2017;29(1):e20160058. DOI

2. Paula S, Rohr EB, Peixoto MCO, Sica CD, Kunzler IM. Análise do desenvolvimento neuropsicomotor de crianças participantes de um programa mãe-bebê. Rev Bras Promoç Saude. 2019;32:8603. DOI

3. Araujo AGS, Stammerjohann J, Círico PC. Avaliação do desenvolvimento motor em crianças de 04 a 24 meses. Cinergis. 2009;10(1):16-22. Full text link

4. Neves KR, Morais RLS, Teixeira RA, Pinto PAF. Growth and development and their environmental and biological determinants. J Pediatr (Rio J). 2016;92(3):241-50. DOI

5. Defilipo EC, Frônio JS, Teixeira MTB, Leite ICG, Bastos RR, Vieira MT, et al. Opportunities in the home environment for motor development. Rev Saude Publica. 2012;46(4):633-41. DOI 
6. Lima MCP, Sena ASS, Câmara CRV, Pinto RMF, Melo ED, Cabral Filho JE. Avaliação do desenvolvimento neuromotor de crianças nascidas a termo e pré-termo nos primeiros seis meses de vida. Fisioter Bra. 2013;14(3):188-92. Full text link

7. Silva ACD, Engstron EM, Miranda CT. Fatores associados ao desenvolvimento neuropsicomotor em crianças de 6-18 meses de vida inseridas em creches públicas do Município de João Pessoa, Paraíba, Brasil. Cad Saude Publica. 2015;31(9):188193. DOI

8. Caçola PM, Gabbard C, Montebelo MIL, Santos DCC. The new affordances in the home environment for motor development - Infant scale (AHEMD-IS): Versions in English and Portuguese languages. Brazilian J Phys Ther. 2015;19(6):507-25. DOI

9. Defilipo EC. Fatores associados à prematuridade e ao baixo peso ao nascer em Governador Valadares, Minas Gerais: estudo caso-controle [tese]. Juiz de Fora: Universidade Federal de Juiz de Fora; 2019. 144 p. Full text link

10. Associação Brasileira de Empresas de Pesquisa (ABEP). Critério de Classificação Econômica Brasil 2015 [cited 2020 Jun 10]. Available from: http://www.abep.org/criterio-brasil

11. Piper M, Darrah J. Motor Assessment of the Developing Infant. Philadelphia: Saunders; 1994. 222 p.

12. Darrah J, Redfern L, Maguire TO, Beaulne AP, Watt J. Intraindividual stability of rate of gross motor development in fullterm infants. Early Hum Dev. 1998;52(2):169-79. DOI

13. Zago JTC, Pinto PAF, Leite HR, Santos JN, Morais RLS. Associação entre o desenvolvimento neuropsicomotor e fatores de risco biológico e ambientais em crianças na primeira infância. Rev CEFAC. 2017;19(3):320-9. DOI

14. Willrich A, Azevedo CCF, Fernandes JO. Desenvolvimento motor na infância: influência dos fatores de risco e programas de intervenção. Rev Neurocienc. 2009;17(1):51-6. Full text link

15. Defilipo EC, Chagas PSC, Peraro-Nascimento A, Ribeiro LC. Factors associated with low birthweight: a case-control study in a city of Minas Gerais. Rev Saude Publica. 2020;54:71. DOI

16. Bueno EA, Castro AAM, Chiquetti EMS. Influência do ambiente domiciliar no desenvolvimento motor de lactentes nascidos pré-termo. Rev Neurocienc. 2014;22(1):45-52. DOI
17. Giordani LG, Almeida CS, Pacheco AM. Avaliação das oportunidades de desenvolvimento motor na habitação familiar de crianças entre 18 e 42 meses. Motricidade. 2013;9(3):96-104. Full text link

18. Almeida TGA, Caçola PM, Gabbard C, Correr MT, Vilela Jr GB, Santos DCC. Comparisons between motor performance and opportunities for motor stimulation in the home environment of infants from the North and Southwest regions in Brazil. Fisioter Pesqui. 2015;22(2):142-7. DOI

19. Pereira KRG, Saccani R, Valentini NC. Cognição e ambiente são preditores do desenvolvimento motor de bebês ao longo do tempo. Fisioter Pesqui. 2016;23(1):59-67. DOI

20. Veitch J, Timperio A, Crawford D, Abbott G, Giles-Corti B, Salmon J. Is the neighbourhood environment associated with sedentary behaviour outside of school hours among children? Ann Behav Med. 2011;41(3):333-41. DOI

21. Miquelote $A F$, Santos DCC, Caçola PM, Montebelo MIL, Gabbard C. Effect of the home environment on motor and cognitive behavior of infants. Infant Behav Dev. 2012;35(3):32934. DOI

22. Sontag-Padilla LM, Burns RM, Shih RA, Griffin BA, Martin LT, Chandra A, et al. The Urban Child Institute CANDLE Study: Methodological overview and baseline sample description. Santa Monica: RAND Corporation; 2015. 94 p. Full text link

23. Nobre FSS, Costa CLA, Oliveira DL, Cabral DA, Nobre GC, Caçola P. Análise das oportunidades para o desenvolvimento motor (affordances) em ambientes domésticos no Ceará Brasil. Rev Bras Crescimento Desenvolv Hum. 2009;19(1):9-18. Full text link

24. Mori S, Nakamoto H, Mizuochi H, Ikudome S, Gabbard C. Influence of affordances in the home environment on motor development of young children in Japan. Child Dev Res. 2013;2013:898406. Full text link

25. Valadi S, Gabbard C. The effect of affordances in the home environment on children's fine- and gross motor skills. Early Child Dev Care. 2020;190(8):1225-32. DOI

26. Caçola P, Gabbard C, Santos DCC, Batistela ACT. Development of the affordances in the home environment for motor development-Infant scale. Pediatr Int. 2011;53(6):820-5. DOI 
27. Cordazzo STD, Vieira ML. A brincadeira e suas implicações nos processos de aprendizagem e de desenvolvimento. Estud Pesqui Psicol. 2007;7(1):89-101. Full text link

28. Freitas TCB, Gabbard C, Caçola P, Montebelo MIL, Santos DCC. Family socioeconomic status and the provision of motor affordances in the home. Braz J Phys Ther. 2013;17(4):319-27. DOI

29. Zoghi A, Gabbard C, Shojaei M, Shahshahani S. The impact of home motor affordances on motor, cognitive and social development of young children. Iran J Child Neurol. 2019;13(2):61-9. Full text link 